\title{
QUALITY MANAGEMENT FOR LEATHER INDUSTRY TO INCREASE COMPETITIVENESS IN THE GLOBAL MARKET
}

\author{
Maya IRJAYANTI ${ }^{1 *}$ \\ Anton Mulyono AZIS²
}

Received: June 2021 | Accepted: July 2021 | Published: August 2021

Please cite this paper as: Irjayanti, M., Azis, A.M. (2021) Quality management for leader industry to increase competitiveness in the global market, Holistica Journal of Business and Public

Administration, Vol. 12, Iss. 2, pp.16-30

\begin{abstract}
The Indonesian government is targeting leather products, especially from West Java to become one of the export commodities that will encourage national economic growth. The existence of a leather industry particularly in the city of Garut has attracted many Indonesian researchers over the years to investigate the condition through many fields of research. However, the latest research identified several barriers related to the leather business development in Garut city, which was related to the optimization ratio of its performance and product quality. This study aimed to design a quality management model and key performance indicators to make this sector competitive in the global market. The research method used was inductive with a qualitative approach and a constructivist grounded theory in developing a quality management model. Theoretical and snowball sampling was chosen in identifying potential participants. The findings of this study contribute to the knowledge and practice of quality management models with key performance indicators that can be used to measure current conditions as a foundation for future improvement in the leather industry to produce competitive products that meet global standard. KPIs were formulated with certain criteria and should be applied by business actors.

Keywords: Performance; Operation; KPI; Leather Industry
\end{abstract}

\section{Introduction}

The centre of the leather industry in the city of Garut has been studied for years by Indonesian researchers from various research fields such as quality management, supply chain, entrepreneurial orientation, employee health, waste management, and the use of

\footnotetext{
${ }^{1}$ Ekuitas School of Business. P.H.H Mustofa 31 Bandung, West Java, Indonesia. E-mail address: maya.irjayanti@ekuitas.ac.id.

* Corresponding author.

2 Ekuitas School of Business. P.H.H Mustofa 31 Bandung, West Java, Indonesia. E-mail address: anton.mulyono@ekuitas.ac.id.
} 
HOLISTICA Vol 12, Issue 2, 2021, pp.16-30

information technology (Aslamiah \& Zulfikar, 2019; Desyanawati \& Siagian, 2019; Dewi \& Gomulia, 2011; Dora \& Putri, 2018; Dzikron, Ceha, \& Muhammad, 2016; Edison, Kartika, \& Lestari, 2017; Fajar, 2018; Gandara, 2019; Garnida \& Hidayat, 2018; Satyarini \& Palesangi, 2012; Setiawan, Rukmi, \& Bakar, 2015; Sumarni, 2018; Suryaman \& Maqin, 2018). However, in the latest research, there are still various obstacles faced by the leather business in the city of Garut, which are related to the inadequate achievement of performance and product quality (Aslamiah \& Zulfikar, 2019; Satyarini \& Palesangi, 2012), thus the government has targeted leather products from the city of Garut to become one of the export commodities. Another obstacle faced by the leather industry in the city of Garut is the absence of a leather business license for export activities and certification standards that must be fulfilled by the leather business (Ulum, 2018). Several leather business actors stated that they had difficulty developing their marketing strategy due to business fund constraints (Satyarini \& Palesangi, 2012; Ulum, 2018), which limited the supply to local markets. Moreover, the inventory management for raw materials has not been properly managed (Satyarini \& Palesangi, 2012). The status of most leather businesses is registering 'survival' levels rather than building a long-term vision for business development (Satyarini \& Palesangi, 2012). This contradicts the fact that Garut is a city famous for its native sheep genetic resources (SDGT) in West Java, the SDGT being one of the essential materials for making leather products in the Garut centre of the leather industry (Desyanawati \& Siagian, 2019). Raw materials and human resources are potential strengths for the Garut leather industry centre (Aslamiah \& Zulfikar, 2019; Satyarini \& Palesangi, 2012), that can be used to expand the marketing of the products to the global market.

This study aims to identify the current conditions of business actors in the leather industry located in the centre of Garut city, especially those related to aspects of operations management to create a quality management model containing key performance indicators. The quality management model built in this study is expected to contribute to science and management in the form of a valid model for the leather industry in Indonesia, with an emphasis on business internationalisation. This research was conducted to support government programs in the empowerment of small and mediumsized enterprises (SME). The role of SMEs is very important for the sustainability of the country, because these enterprises represent the backbone of the national economy, especially in the context of the global crisis (Irjayanti \& Azis, 2013; Irjayanti, Azis, \& Sari, 2016, 2018; Tambunan, 2019).

The results of the study will be discussed based on the formulation of responses for the following research questions: (1) What are the latest constraints faced by leather entrepreneurs in the city of Garut?; (2) What kind of quality management is known and has been carried out by business actors?; (3) What potential KPIs are most relevant to the conditions of business actors that will increase product competitiveness? 


\section{Literature Review}

Today, enterprises face more complicated business scenarios due to various demands that require them to adapt to the character and demands of customers, technology adoption, and integration with global markets (Centobelli, Cerchione, \& Ertz, 2020; Mukonza \& Swarts, 2020). Almost all types of businesses, including leather processing businesses, experience problems regarding product quality, increased product diversity, and constant market fluctuations that make business challenges even more severe (Agrawal \& Singh, 2019; Moktadir et al., 2020; Omoloso, Mortimer, Wise, \& Jraisat, 2020; Paul, Antunes, Covington, Evans, \& Phillips, 2013). The leather, leather goods and footwear manufacturing industries are under high pressure to innovate their operational performance in the face of recent advances (Moktadir et al., 2020). The leather industry is forced to improve and carry out automation, especially those related to manufacturing activities (Kazancoglu, Sagnak, Kayikci, \& Kumar Mangla, 2020).

Recent research related to the leather industry sector in Bangladesh found that this sector is an important domain for the country's financial growth (Moktadir et al., 2020). To maintain its competitive advantage, this industrial sector is required to be able to react and adapt to the modifications created by an ambiguous environment (Dahlmann \& Roehrich, 2019; Moktadir et al., 2020). One proactive way of responding to the market conditions on behalf of the leather industry sector is represented by the practice of business excellence (Moktadir et al., 2020). Excellence in operations is one of the approaches that help the leather industry sector to navigate via the right path to achieve its business goals (Moktadir et al., 2020).

Achieving a superior level in operations is related to quality management that is relevant to increasing industrial productivity by adopting a best practice approach (Moktadir et al., 2020). Several studies suggest the importance of investigating key performance indicators (KPIs), especially for the leather products industry (Moktadir et al., 2020). This activity is important to identify significant and insignificant KPIs related to the excellence of operations management for long-term business continuity.

In managing quality management, KPIs play an important role for organizations and businesses to understand their performance and its relevance to achieving goals. KPI is an effective instrument in quality management to measure performance which can be used as an illustration of management success, especially in the operational field (Horta, Camanho, \& Da Costa, 2010). KPIs help an organization to identify operations that are performing well, and operations that need improvement in the future. The determination of KPIs depends on the conditions of the organization/business and the goals to be achieved, however, an organization/business can adopt the best practices from similar organizations/businesses as the basis for creating a KPI model. Certainly, the preparation of KPIs must be based on the principles of effectiveness and efficiency because these are important, especially in today's business environment. In quality management, KPI is indispensable to achieve operational excellence towards sustainability as an information and planning foundation (Horta et al., 2010). In addition, KPI is also able to present an 
approach to visualize whether a strategic plan can determine higher chances of objective completion. One thing is certain: the application of KPIs can lead to an increase in organizational productivity and profitability (Horta et al., 2010).

In the literature review, not many studies discuss KPIs that are relevant to the leather industry (Moktadir et al., 2020). One study that specifically analyses the operational performance indicators of the leather industry in Ethiopia places more emphasis on the customer preference assessment approach (Addis, Dvivedi, \& Beshah, 2017). The analysis of the study identified five KPI indicators that have a high influence on the production performance of the Ethiopian leather industry (Addis et al., 2017). The results of these studies indicate that flexibility and quality are the most important indicators for improving industrial production performance.

Based on previous research, the discussion of KPIs in business or industry focuses on the KPI categories in the fields of management, operations, quality, economy, and the environment (Moktadir et al., 2020). Specifically, the KPI categories found in recent studies (performed in the last ten years) in various industrial fields (Moktadir et al., 2020) include:

- Management KPIs with sub-KPIs covering efficiency in facility use and facility usage management (Kaganski, Majak, \& Karjust, 2018).

- Operation KPIs with sub-KPIs of production scheduling (Bag, Wood, Xu, Dhamija, \& Kayikci, 2020), fulfilment of work completion time targets (Rabhi, 2011), machine maintenance (Mydin, 2014).

- Quality KPIs with sub-KPIs consisting of customer satisfaction (Sawang, 2011), low number of defective products (Anggradewi, Aurelia, \& Ekawati, 2019), and the application of TQM in the industry (Friedli, Goetzfried, \& Basu, 2010).

- Economic KPIs with net income sub-KPIs (Demydyuk, 2012).

- Social KPIs with sub-KPIs on worker safety (Dixit, Yadav, Dwivedi, \& Das, 2015; Zou \& Moon, 2014) and worker satisfaction (Edison et al., 2017; Tsai \& Cheng, 2012).

- Environmental KPIs with environmental management system sub-KPIs (Kylili, Fokaides, \& Jimenez, 2016), levels of greenhouse gas emissions (Kourkoumpas et al., 2018), and levels of emissions to water and soil (de Aquim, Hansen, \& Gutterres, 2019).

While other recent studies related to the leather industry in Indonesia also found several important elements for potential KPIs that are relevant to quality management, including:

- $\quad$ The use of information technology for product marketing (Dora \& Putri, 2018).

- Adoption of the latest technology for the production process (Desyanawati \& Siagian, 2019).

- $\quad$ Finance and capital structure (Dewi \& Gomulia, 2011).

- Market orientation and entrepreneurial orientation (Fajar, 2018; Rawati, Muharam, \& Kartiko, 2019). 
- Waste management (Moelyo, 2012), and worker health (Sumarni, 2018).

All KPIs identified above will be used as a basis for gathering information and answering the current research questions. This research is hitting an important milestone since 2011 which focuses on researching small and medium enterprises in various sectors. Starting in 2012, the focus of research on SMEs is prioritized on several creative industry sectors including the fashion sector (and its derivative products), handicrafts, and traditional culinary. Garut leather centre is part of the creative industry sector because leather derivative products are products related to the fashion sector which may consist of clothes (jacket), bags, shoes, and other relevant products.

There has been no research that has created a quality management model in the industrial centre of the city of Garut, even though this is important considering the government's target to make this leather centre one of the export commodities in the future. Therefore, the quality management model and key performance indicators are important to describe the current position of the leather business and can be used as a basis for quality improvement towards global competitiveness.

This research was conducted to support government programs in efforts to develop the creative industry sector in Indonesia as one of the sectors that makes a significant contribution to the gross domestic product in Indonesia (Mansur, 2014; Musyaffa, 2017; Purnomo, 2016).

\section{Research Method}

This study is proposing an inductive research with qualitative research methods with a constructivist grounded theory strategy. The reason that underlies the choice of this strategy was the absence of previous research in Indonesia that specifically discusses the standard key performance indicators comprehensively in the leather industry centre of Garut city for creating quality management for global competitive purpose. Therefore, the constructivist grounded theory strategy is relevant for this research, considering that the grounded theory strategy is intended for research that aims to create a theoretical model that answers research questions.

Constructivist grounded theory is a qualitative research strategy that presents data in a constructive manner (Charmaz, 2017). Constructivist grounded theory is a remodelling of the classical grounded theory strategy invented by Barney Glaser and Anselm L. Strauss (Glaser, 2010) around 1960. Grounded theory is a qualitative research strategy that aims to produce theory systematically through a series of data analysis processes (Jones \& Alony, 2011). This strategy does not require researchers to conduct literature reviews as a basis for a theoretical framework in the data collection process, however, constructivist grounded theory (Charmaz, 2017) suggests researchers to fill their heads with knowledge before entering the research field to retrieve data. The role of literature review in a grounded theory strategy is to enrich the knowledge of researchers related to the research to be carried out. 
Participants in this study were obtained using theoretical sampling and snowball sampling. Theoretical sampling was carried out by selecting participants who meet certain criteria with knowledge and information to assist researchers in building theory, for instance, the participants with at least five years of experience in the leather business and were actively involved in the operational management in the leather industry. Meanwhile, snowball sampling was also utilized as a sampling strategy by asking interviewed participants to recommend other participants with an adequate level of knowledge. In general, the number of samples or participants in qualitative research depends on the saturation of the data. Interviews usually reach saturation with an average number of 10 to 12 participants (Saunders, Lewis, \& Thornhill, 2016). However, the data collections need to be continued when the data has not reached saturation.

Interviews were conducted face-to-face and with the participant's consent, the interview process will be recorded with an audio recording. The results of the recording during the interview will be constructed under the form of a transcription containing the interview text for further analysis.

\section{Findings and Discussion}

The leather industry in Garut city which is centred in Sukaregang area has existed since decades ago in the early 1900s. The leather industry in this area has experienced a long journey for its development in the process of production activity. Before the pandemic, Garut leather products have succeeded in attracting shopping tours of domestic and foreign tourists, thus, their potential should be developed so the products meet the quality in global competitiveness. Sukaregang Leather Industry is divided into two industrial sectors: the leather tanning industry and the leather craft industry located in Garut City. Currently, there are 387 leather tanning business units with total production reaching more than 29 million feet/year employing more than 1600 workers and for nontanning industry (leather crafts) reaching 247 business units with a production capacity of 1,708,600 pieces/year employing 1366 workers.

At this stage, the Department of Cooperatives and SMEs in Garut City has recorded that the annual production of Leather Jackets amounted to only 250,000 pieces. Before the pandemic, there was always a demand especially for leather jackets from many areas outside Garut. With the support of the government, Leather jackets made in Garut have also become available on international markets, such as Singapore, Malaysia, Taiwan, China and Japan. Based on the latest data, Garut leather jackets were exported to Singapore, Malaysia, Taiwan, and Australia with a volume of 9,488 pieces valued at US\$448,464. This shows a good increase in exports compared to the previous export volume of 5,100 pieces worth US\$258,651. The obstacles faced involved the processing technology to accelerate the production process and the quality control of the goods that can affect the performance of the commodity image of Indonesian leather product. If these obstacles are not overcome, the Garut leather craftsmen will be unable to compete with leather products from other regions or countries in the global market. 
HOLISTICA Vol 12, Issue 2, 2021, pp.16-30

The three operational stages of the leather industry which include input, process and output involved not only the community in Garut but also external parties who were the material suppliers and the leather tanning industry. The positive impact of the existence of this leather industry was the labour absorption number as main input besides the material for the production process. Also, this industry encourages the development of supporting businesses such as leather suppliers and leather tanners. The following picture illustrates how the leather industry develops by involving many parties in the production process.

Figure 1 The operational stages in leather industry

\begin{tabular}{|c|c|c|}
\hline Essential Inputs & Process & Output \\
\hline $\begin{array}{l}\text { 1. Material from } \\
\text { external supplier } \\
\text { 2. Tanned leather } \\
\text { by external } \\
\text { tanning industry } \\
\text { for making it } \\
\text { ready to } \\
\text { processed } \\
\text { 3. Garut } \\
\text { community as a } \\
\text { freelance workers } \\
\text { 4. Special } \\
\text { purpose machine }\end{array}$ & $\begin{array}{l}\text { 1. Tannery } \\
\text { 2. Skin coloring } \\
\text { 3. Product design } \\
\text { 4. Making design } \\
\text { patterns } \\
\text { 5. Cutting } \\
\text { 6. Skin suturing } \\
\text { 7. Quality } \\
\text { checking } \\
\text { 8. Waste } \\
\text { treatment }\end{array}$ & $\begin{array}{l}\text { Leather products: } \\
\text { 1. Women's and } \\
\text { men's jackets } \\
\text { 2. Women's and } \\
\text { men's bags } \\
\text { 3. Women's and } \\
\text { men's wallets } \\
\text { 4. Women's and } \\
\text { men's shoes } \\
\text { 5. Prayer mats } \\
\text { 6. Other leather } \\
\text { accessories }\end{array}$ \\
\hline
\end{tabular}

Source: Authors' synthesis, 2021.

Based on data analysis procedures in grounded theory research, data analysis was carried out in three stages: open coding, axial coding, and selective coding. Open coding was the first stage of coding that highlights all words and sentences that were relevant to the research question and then grouped them into certain themes and then these themes were grouped into a larger group of themes referred to as "categories" at the axial coding stage. Furthermore, after the various categories were formed at the axial coding stage, the researcher looked for the relationship between these categories as a basis for constructing a theory at the selective coding stage. In the selective coding stage, all relevant categories will form a core category as a starting point for theory formation.

Various coding found in data analysis are classified into several categories as illustrated in the Figure 2 . 
Figure 2 Coding stage for data analysis

OPEN CODING

Initial start year

- Business motivation

- Business background

- Environment

- Form of business entity

- Production process

- Materials

- Fund

- Tools

- Workers

- Design

- Market

- Customers

- Marketing

- Suppliers

- Production scheduling

- Technology

Barriers
AXIAL CODING

SELECTIVE CODING

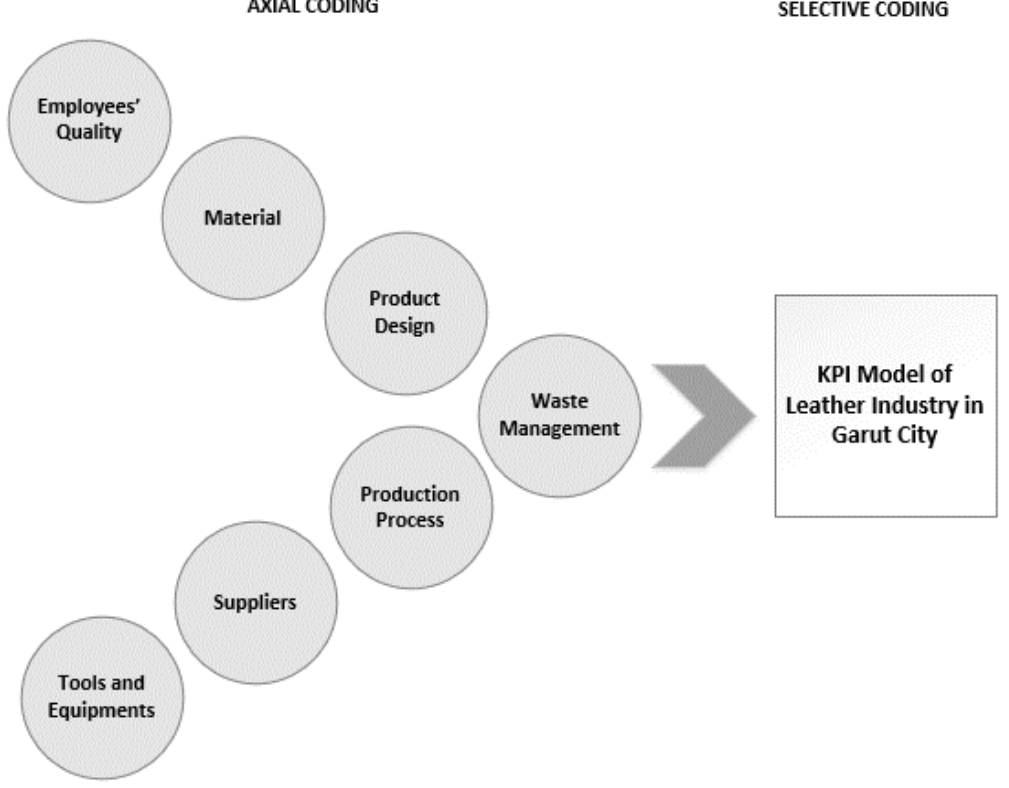

Source: Authors' synthesis, 2021.

Many of the participants stated that the businesses they currently operate are businesses inherited from their parents or their families. So that they are the next generation of the current leather business. The impact of the existence of the leather industry that has existed since decades ago provides excellence and strength for the leather industry in Garut (Cahyana, 2007). These advantages include providing a lot of human resources who have been trained from generation to generation to produce leather-based goods such as jackets, bags, shoes, and leather accessories. These people already understood how to properly machine stitch leather to avoid mistakes. They are also familiar with the various types of machines used to process leather such as cutting, embroidering, and sewing leather. Most of them did not make significant mistakes because they were used to working on and sharing knowledge with newly joined workers. Uniquely, these workers were willing to work without a certain standard of salary but earn income based on the number of products they work on. A supportive work atmosphere and a family-like work environment were factors that have caused employee turnover to be relatively low for decades, this evidence supports many findings in similar literature (Edison et al., 2017).

Many of the participants stated that they work according to certain operational standards. They are equipped with knowledge on how to process leather started from tanning, dyeing, pattern drafting, cutting, and sewing the leather sheet. This qualification is essential especially for job performance as mentioned in a recent study by Edison et al. (2017). All participants claimed they worked within a "make to order" system from the customers who purchased their products in large quantities. Moreover, the product 
HOLISTICA Vol 12, Issue 2, 2021, pp.16-30

designs were tailored to the demands of the customer. If a complaint was notified, the participants claimed that they treated the situation very well and made improvements until the products met the buyer's expectations.

In this study, several findings noted barriers in the leather industry in Garut city. Apart from the impact of the pandemic, most industries do not have adequate waste management processes to prevent environmental pollution (Gandara, 2019; Suryaman \& Maqin, 2018). Threats to waste mainly occur in the supporting industry of the leather industry, for instance, the tanning industry, where the raw leather was processed using certain chemicals, and then, under the leather industry's guidelines, processed into finished products such as jackets, bags, shoes and another leather products. The leather processing industry, especially the tanning industry, generally did not produce for sale inventory. They mostly work on order-based systems, since only large stores continue to produce even when there were no orders recorded. These stores made products for displayed selling products in their shop. They also started online marketing campaigns for their online stores, using website and social media platforms as channels of communication with their customer base.

From the data analysis, the key performance indicators relevant for the performance and quality in global competitiveness were illustrated in the following model.

Figure 3 Key performance indicators for quality management

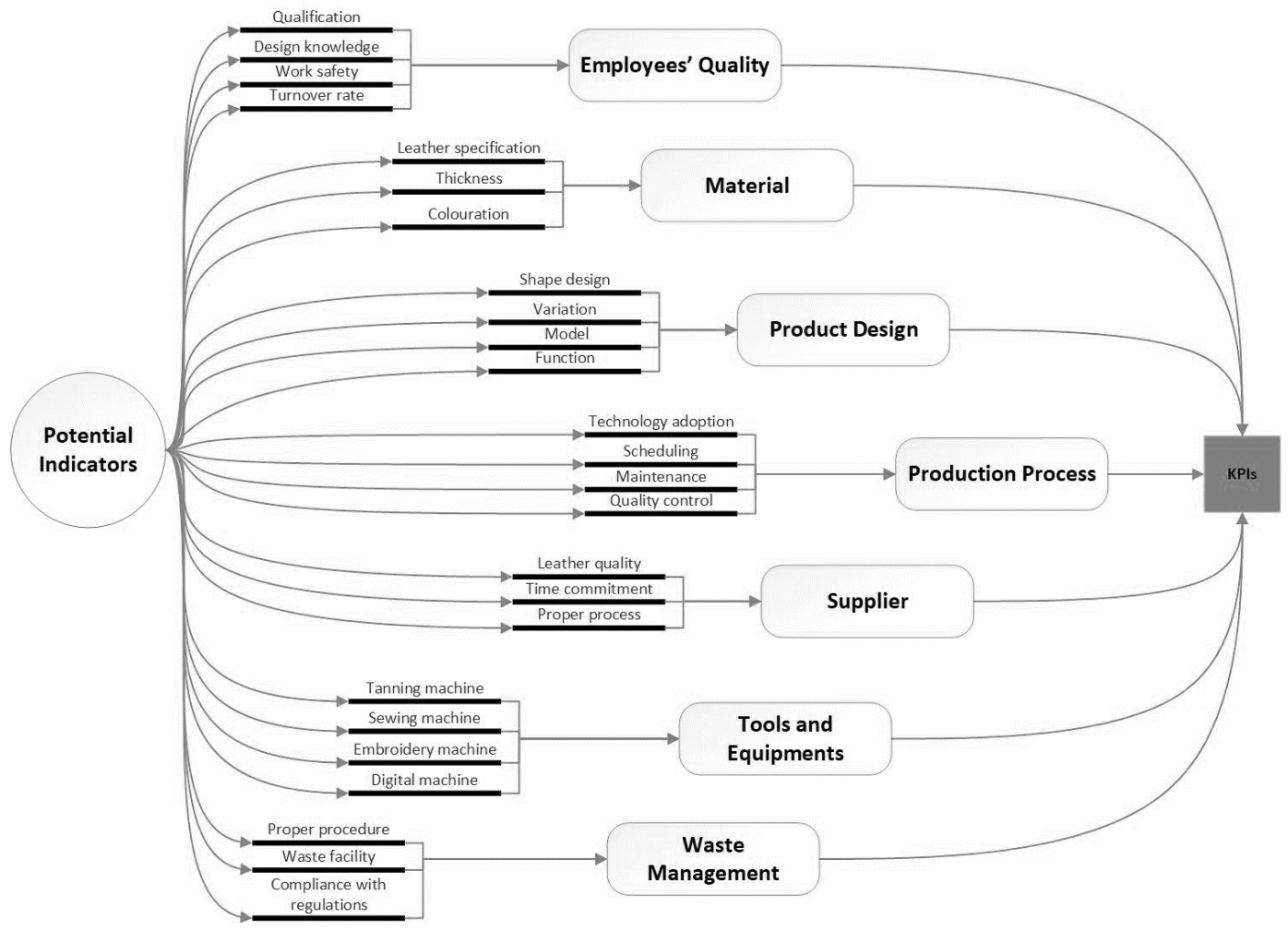

Source: Authors' synthesis, 2021. 
HOLISTICA Vol 12, Issue 2, 2021, pp.16-30

The elements most frequently revealed by the participants were the quality of workers, raw materials, product design, production processes, suppliers, tools and equipment, and waste management. These seven elements were designed by various indicators highlighted by participants based on their essential role in ensuring the quality of the final product and company performance. These indicators within each KPI can be measured quantitatively or qualitatively depending on what information that the business wants to be gathered.

However, the participants admitted that not all the elements mentioned have been carried out in their operational process. There were many elements that they have not conducted as they faced many problematic barriers. They expected supports from the local government to solve the problems since they lacked resources, especially during the pandemic.

Several barriers faced by these leather industries in Garut were identified as follows:

- The marketing strategy to reach the global market still relies on the cooperation of the third party who came to their locations, there has been no initiative identified from industry players to initiate global trade possibilities.

- Global promotion experience by participating the government programs through various international exhibitions, besides that there has been no effort from industry players to participate independently.

- Marketing activities by using digital technology has only been carried out after a pandemic occurred so that product awareness has not yet reached all expected market segments. This finding responds to the study conducted by (Dora \& Putri, 2018) related to the importance of the adoption of information technology as a marketing strategy. Previously, business operators still relied on visits from tourists to buy their products at shops.

- The product was not professionally designed (with proper designers). Most products were designed as a response to the buyers' tastes, or the owners' idea, or the input from workers.

- The technology adopted for the production process utilized dated technology that has been used for decades. The main reason why the business actors did not update the technology was the limited business fund to renew the proper equipment and machinery.

- The tanning industry did not have an adequate waste management process. At this stage, they utilized the traditional method by using a certain mixture to precipitate chemical substances before the liquid waste from the tannery is discharged into the river. Auditions with the government have been conducted several times but still have not found a solution due to bureaucratic and budgetary difficulties. Most business actors are micro, small and medium industries for which have not been able to bear the costs of managing waste 
independently because it requires special installations in its management. A recent study conducted by de Aquim et al. (2019) could be a temporary solution for the situation.

The obstacle that is essential for the leather industry in Garut at this moment is that most industries do not have adequate waste management processes to prevent environmental pollution. Since the initiation of the establishment of a leather business in Garut decades ago, there has been no effort to manage liquid waste especially from the tanning process. The threat of waste mainly occurs in the leather industry supporting industries, for example in the tanning industry, wherein this process raw leather was processed using certain chemicals so that the leather could be processed into finished products such as jackets, bags, shoes, and other leather accessories. Constraints related to waste management have lasted for decades but have not yet found a common ground that could benefit all parties. This was due to the high cost of waste facility installation that needs to be built for each leather processing business in Garut which reaches more than 50 tanning businesses. The ministry has assisted by building five sewage treatment plants (called IPL), but this waste management facility has not been used because it required other equipment to operate it such as pipes from each factory or a leather tanning business to drain the wastewater from the tanning process to the IPL facility. There was no agreement reached regarding who fund this facility. At this stage, the waste was managed simply, by using a certain solution or a substance to precipitate the chemical before the waste was discharged into the river. Many of the tannery businesses (which became the main actors producing liquid waste) were businesses that operated on a micro, small and medium scale. Their small business margin made it impossible to allocate a certain amount of money for the processing of liquid waste. The funds needed to manage the liquid waste were very expensive for these local entrepreneurs. Auditions with the government have been carried out many times over the years, but there has been no solution available for this matter at this stage. This research is expected to influence government policies that can bridge the problems faced by small business actors so that they do not violate the law while operating in the leather industry. The government needs to consider an integrated waste management system that does not burden the leather industry players because their current financial condition does not allow them to build a liquid waste management plant. The government needs to support not only from the marketing aspect but also from the problem coming from the leather production's waste to prevent environmental pollution in the long term.

In winning the global competition, all elements that are important criteria for acceptance in the global market need to be met. These elements were derived from the key performance indicators that will help control the quality of the leather business from upstream to downstream industries. Focus on achieving the seven KPI elements identified in this study is considered as a potential solution to achieve a competitive advantage for Garut City leather products especially in the global market. 


\section{Conclusions}

To position the leather industry in global competition, several KPIs need to be addressed as standards in engaging the competition through the quality standard of product and production. Many KPIs have been identified in this study and meet the criteria for this leather industry to compete in the global market, however, several KPIs significantly reveal the potential that will hinder the development of the leather industry in Garut city towards global competition. The leather industry in Garut utilized dated equipment and machines although it is still suitable for use. In addition, they use a modest approach in creating product designs, the role of professional designers is not mentioned in this study. New marketing activities using information technology was conducted after the pandemic, which has caused the business conditions to be relatively low compared to the period before the pandemic. The most potential KPIs as a threat for its development related to the environmental pollution from leather processing waste that has not met environmental health criteria.

\section{References}

Addis, S., Dvivedi, A., \& Beshah, B. (2017). Identifying and prioritising operational performance indicators of the Ethiopian leather industry. International Journal of Productivity and Quality Management, 22(3): 378-394.

Agrawal, S., \& Singh, R. K. (2019). Analyzing disposition decisions for sustainable reverse logistics: Triple Bottom Line approach. Resources, Conservation and Recycling, 150: 1-11.

Anggradewi, P., Aurelia, S., S, \& Ekawati, A. D. (2019). Improving quality in service management through critical key performance indicators in maintenance process: A systematic literature review. Quality - Access to Success, 20(173): 72-79.

Aslamiah, R. S., \& Zulfikar, R. (2019). Pengaruh Pengembangan Produk dan Pengendalian Kualitas terhadap Kinerja Perusahaan (Survei Pada Sentra Astiga Leather Garut). Universitas Komputer Indonesia.

Bag, S., Wood, L. C., Xu, L., Dhamija, P., \& Kayikci, Y. (2020). Big data analytics as an operational excellence approach to enhance sustainable supply chain performance. Resources, Conservation and Recycling, 153: 1-10.

Cahyana, I. (2007). Peran Pemerintah Daerah dalam Mengembangkan Klaster Industri Kulit di Kabupaten Garut. Universitas Diponegoro.

Centobelli, P., Cerchione, R., \& Ertz, M. (2020). Managing supply chain resilience to pursue business and environmental strategies. Business Strategy and the Environment, 29(3): 1215-1246.

Charmaz, K. (2017). The Power of Constructivist Grounded Theory for Critical Inquiry. Qualitative Inquiry, 23(1), 34-45. doi:10.1177/1077800416657105

Dahlmann, F., \& Roehrich, J. K. (2019). Sustainable supply chain management and partner engagement to manage climate change information. Business Strategy and the Environment, 28(8): 1632-1647.

de Aquim, P. M., Hansen, É., \& Gutterres, M. (2019). Water reuse: An alternative to minimize the environmental impact on the leather industry. Journal of environmental management, 230: 456-463.

Demydyuk, G. (2012). Optimal financial key performance indicators: evidence from the airline industry. Accounting \& Taxation, 3(2): 39-51. 
HOLISTICA Vol 12, Issue 2, 2021, pp.16-30

Desyanawati, A., \& Siagian, M. C. A. (2019). Eksplorasi Material Kulit Domba Dengan Teknik Laser Cut Pada Designer Wear. eProceedings of Art \& Design, 6(2): 1787-1794.

Dewi, V. I., \& Gomulia, B. (2011). Struktur Modal Usaha Kecil Sentra Kulit di Sukaregang, Garut. Bina Ekonomi, 15(2): 1-15.

Dixit, S., Yadav, A., Dwivedi, P. D., \& Das, M. (2015). Toxic hazards of leather industry and technologies to combat threat: a review. Journal of Cleaner Production, 87: 39-49.

Dora, Y. M., \& Putri, R. K. (2018). Pemanfaatan Teknologi Informasi Bagi Pengembangan Pemasaran Produk UMKM Industri Kulit (Studi pada Kawasan Sentra Kulit Sukaregang Garut-Jawa Barat). Paper presented at the Seminar Nasional Pengabdian Kepada Masyarakat (PKM).

Dzikron, M., Ceha, R., \& Muhammad, C. R. (2016). Perbaikan Kinerja Operasional Industri Penyamakan Kulit dengan Pendekatan Supply Chain dan Lean Manufacturing (Kasus Industri Kulit Sukaregang). Teknoin, 22(8): 584-594.

Edison, E., Kartika, T., \& Lestari, R. I. D. (2017). Pengaruh Kepuasan Kerja dan Kompetensi terhadap Kinerja Karyawan di Sentra Industri Kulit Sukaregang. Barista: Jurnal Kajian Bahasa dan Pariwisata, 4(1): 51-60.

Fajar, G. G. (2018). Pengaruh Orientasi Pasar dan Orientasi Kewirausahaan terhadap Kinerja Penjualan (Studi Kasus pada Sentra Industri Kulit Desa Sukaregang, Garut). Faculty of Social and Political Sciences.

Friedli, T., Goetzfried, M., \& Basu, P. (2010). Analysis of the implementation of total productive maintenance, total quality management, and just-in-time in pharmaceutical manufacturing. Journal of Pharmaceutical Innovation, 5(4): 181-192.

Gandara, K. K. (2019). Kebijakan Pemerintah Daerah Kabupaten Garut dalam mengatasi limbah penyamakan kulit Di Kecamatan Sukaregang Kabupaten Garut. UIN Sunan Gunung Djati Bandung.

Garnida, F. G., \& Hidayat, W. (2018). Pengaruh Orientasi Pasar dan Orientasi Kewirausahaan terhadap Kinerja Penjualan UMKM pengrajin kulit (Studi pada Sentra Industri Pengrajin Kulit Desa Sukaregang, Garut). Jurnal Ilmu Administrasi Bisnis, 7(3): 196-205.

Glaser, B. G. (2010). The future of grounded theory. The Grounded Theory Review, 9(2): 1-14.

Horta, I. M., Camanho, A. S., \& Da Costa, J. M. (2010). Performance assessment of construction companies integrating key performance indicators and data envelopment analysis. Journal of Construction engineering and Management, 136(5): 581-594.

Irjayanti, M., \& Azis, A. M. (2013). Success factors of fast-moving goods of small medium enterprises in Indonesia'. Journal of Global Entrepreneurship, 4(1): 17-30.

Irjayanti, M., Azis, A. M., \& Sari, P. A. (2016). Indonesian SMEs readiness for ASEAN economic community. Actual Problems in Economics, (177): 31-38.

Irjayanti, M., Azis, A. M., \& Sari, P. A. (2018). Indonesian SMEs readiness for ASEAN economic community.

Jones, M., \& Alony, I. (2011). Guiding the use of grounded theory in doctoral studies. International Journal of Doctoral Studies, 6: 95-114.

Kaganski, S., Majak, J., \& Karjust, K. (2018). Fuzzy AHP as a tool for prioritization of key performance indicators. Procedia Cirp, 72: 1227-1232.

Kazancoglu, Y., Sagnak, M., Kayikci, Y., \& Kumar Mangla, S. (2020). Operational excellence in a green supply chain for environmental management: A case study. Business Strategy and the Environment, 29(3): 1532-1547.

Kourkoumpas, D.-S., Benekos, G., Nikolopoulos, N., Karellas, S., Grammelis, P., \& Kakaras, E. (2018). A review of key environmental and energy performance indicators for the case of renewable energy systems when integrated with storage solutions. Applied Energy, 231: 380-398. 
Kylili, A., Fokaides, P. A., \& Jimenez, P. A. L. (2016). Key Performance Indicators (KPIs) approach in buildings renovation for the sustainability of the built environment: A review. Renewable and Sustainable Energy Reviews, 56: 906-915.

Mansur, A. (2014). Peran Industri Kreatif Vital Bagi Ekonomi Indonesia. Accessed October 20, 2020. http://www.neraca.co.id/article/48086/peran-industri-kreatif-vital-bagi-ekonomiindonesia.

Moelyo, M. (2012). Pengkajian Evektifitas Proses Koagulasi Dalam Memperbaiki Kualitas Limbah Industri Penyamakan Kulit-Sukaregang, Garut. Jurnal Teknik Hidraulik, 3(2): 169-182.

Moktadir, M. A., Dwivedi, A., Rahman, A., Chiappetta Jabbour, C. J., Paul, S. K., Sultana, R., \& Madaan, J. (2020). An investigation of key performance indicators for operational excellence towards sustainability in the leather products industry. Business Strategy and the Environment, 29(8): 3331-3351.

Mukonza, C., \& Swarts, I. (2020). The influence of green marketing strategies on business performance and corporate image in the retail sector. Business Strategy and the Environment, 29(3): 838-845.

Musyaffa, I. (2017). Peran industri kreatif pada perekonomian Indonesia. Accessed October 20, 2020. https://www.aa.com.tr/id/ekonomi/peran-industri-kreatif-pada-perekonomianindonesia/952584.

Mydin, M. A. (2014). Key Performance indicator of building maintenance and its effect on the building life cycle. Analele Universitatii Eftimie Murgu, 21(1): 193-202.

Omoloso, O., Mortimer, K., Wise, W. R., \& Jraisat, L. (2020). Sustainability Research in the Leather Industry: a critical review of progress and opportunities for future research. Journal of Cleaner Production, 285: 1-11.

Paul, H., Antunes, A. P. M., Covington, A. D., Evans, P., \& Phillips, P. S. (2013). Bangladeshi leather industry: An overview of recent sustainable developments. Journal of the Society of Leather Technologists and Chemists, 97(1): 25-32.

Purnomo, R. A. (2016). Ekonomi Kreatif Pilar Pembangunan Indonesia. Accessed October 20, 2020. www.nulisbuku.com.

Rabhi, M. (2011). Key performance indicators metrics effect on the advancement and sustainability of knowledge management. Electronic Journal of Knowledge Management, 9(2): 149-154.

Rawati, F., Muharam, H., \& Kartiko, E. (2019). Orientasi Wirausaha dan Network Capability dalam Upaya Peningkatan Kinerja pada IKM Penyamakan Kulit di Sukaregang Kabupaten Garut. Jurnal Wacana Ekonomi, 19(1): 001-012.

Satyarini, R., \& Palesangi, M. (2012). Analisis Peluang dan Tantangan Pada Paguyuban Cahaya Terang Sebagai UKM Pengrajin Kulit di Sukaregang Garut. Research Report-Humanities and Social Science, 1.

Saunders, M., Lewis, P., \& Thornhill, A. (2016). Research Methods for Business Students, $7 E$. England: Pearson Education Limited.

Sawang, S. (2011). Key performance indicators for innovation implementation: Perception vs. actual usage. Asia Pacific Management Review, 16(1): 23-29.

Setiawan, A., Rukmi, H. S., \& Bakar, A. (2015). Strategi Pengembangan UKM Pengolahan Kulit Sapi di Kabupaten Garut Menggunakan Matrik Perumusan Strategi. REKA INTEGRA, 3(3): 218229.

Sumarni, N. (2018). Faktor-faktor yang Mempengaruhi Kejadian Dermatitis Kontak pada Pekerja Penyamakan Kulit di Perusahaan VPC Sukaregang Garut. Paper presented at the Prosiding Seminar Bakti Tunas Husada, STIKes Bakti Tunas Husada Tasikmalaya. 
HOLISTICA Vol 12, Issue 2, 2021, pp.16-30

Suryaman, R. A., \& Maqin, H. R. A. (2018). Dampak Eksternalitas dari Keberadaan Sentra Industri Penyamakan Kulit Sukaregang. Fakultas Ekonomi dan Bisnis Unpas Bandung,

Tambunan, T. (2019). Recent evidence of the development of micro, small and medium enterprises in Indonesia. Journal of Global Entrepreneurship Research, 9(1). doi:10.1186/s40497-0180140-4

Tsai, Y. C., \& Cheng, Y. T. (2012). Analyzing key performance indicators (KPIs) for E-commerce and Internet marketing of elderly products: A review. Archives of Gerontology and Geriatrics, 55(1): 126-132.

Ulum, U. R. (2018). Uu Bakal Genjot Produktivitas Sentra Industri Kulit Garut. Accessed October 20, 2020. https://m.ayotasik.com/read/2018/04/20/1256/uu-bakal-genjot-produktivitassentra-industri-kulit-garut.

Zou, X., \& Moon, S. (2014). Hierarchical evaluation of on-site environmental performance to enhance a green construction operation. Civil Engineering and Environmental Systems, 31(1): 5-23. 